\title{
Pengaruh Pendekatan Kontekstual terhadap Kemampuan Penalaran Matematis Ditinjau dari Gaya Kognitif Peserta Didik
}

\author{
Nosva Adam Yunus ${ }^{*}$, Ismail Djakaria ${ }^{2}$, Evi Hulukati ${ }^{3}$ \\ ${ }^{1}$ Program Studi Magister Pendidikan Matematika, Pascasarjana, Universitas Negeri Gorontalo, \\ Jl. Jenderal Sudirman No. 06, Kota Gorontalo 96128, Gorontalo, Indonesia \\ 2,3 Jurusan Matematika, Fakultas MIPA, Universitas Negeri Gorontalo, \\ Jl. Jenderal Sudirman No. 06, Kota Gorontalo 96128, Gorontalo, Indonesia \\ * Penulis Korespondensi. Email: adamsnosva@gmail.com
}

\begin{abstract}
ABSTRAK
Artikel ini membahas tentang pengaruh pendekatan kontekstual terhadap kemampuan penalaran ditinjau dari gaya kognitif peserta didik. Jenis penelitian Quasi Experiment dengan desain Faktorial $2 \times 2$ menggunakan uji analisis dua jalur dan uji Tukey. Metode pengumpulan data melalui pemberian tes kemampuan penalaran dan Group Embedded Figures Test (GEFT). Temuan penelitian menunjukkan bahwa pada pembelajaran kontekstual subjek bergaya kognitif Field Independent menguasi lebih tiga dari empat indikator pemampuan penalaran matematis dengan nilai $t_{\text {hitung }}=183,55$. Sementara pada pembelajaran langsung, subjek bergaya kognitif Field Independent hanya menguasi kurang tiga dari empat indikator kemampuan penalaran matematis dengan nilai nilai $t_{\text {hitung }}=140,85$. Dengan demikian, terdapat pengaruh pendekatan kontekstual terhadap kemampuan penalaran peserta didik yang mempunyai gaya kognitif Field Independent.
\end{abstract}

Kata Kunci:

Kemampuan Penalaran Matematis; Pendekatan Kontekstual; Gaya Kognitif

\section{ABSTRACT}

This paper discusses about the effect of contextual approaches on reasoning ability in terms of the cognitive style of students. This type of research is Quasi Experiment with $2 \times 2$ Factorial design using two path analysis test and Tukey test. Methods of data collection through the provision of reasoning ability tests and Group Embedded Figures Test (GEFT). The research findings show that in the contextual learning subject Field cognitive style independent holds more than three of the four indicators of mathematical reasoning ability with a $t_{\text {count }}=183,55$. While in direct learning the subject of cognitive style independent Field only takes less than three of the four indicators of mathematical reasoning ability with a value of $t_{\text {count }}=140,85$. Thus, there is the influence of contextual approaches to students' reasoning abilities that are categorized as having independent cognitive field styles.

Keywords:

Mathematical Reasoning Ability; Contextual approach; Cognitive Style

Format Sitasi:

N.A. Yunus, I. Djakaria and E. Hulukati, "Pengaruh Pendekatan Kontekstual terhadap Kemampuan Penalaran Matematis Ditinjau dari Gaya Kognitif Peserta Didik," Jambura J. Math., vol. 2, no. 1, pp.30-38, 2020

e-ISSN: 2656-1344 (C) 2020 N.A. Yunus, I. Djakaria, E. Hulukati| Under the license CC BY-NC 4.0

Diterima: 13 Agustus 2019 | Disetujui: 03 Desember 2019 | Online: 31 Januari 2020 


\section{Pendahuluan}

Matematika termasuk pelajaran yang dapat dijadikan sebagai sarana berpikir untuk menumbuh kembangkan pola pikir logis, sistematis, obyektif, dan kritis. Oleh sebab itu matematika dan penalaran matematika merupakan dua hal yang tidak dapat dipisahkan. Materi matematika dipahami melalui penalaran dan penalaran dilatih melalui pelajaran matematika.

Penalaran juga merupakan salah satu aspek kemampuan yang termasuk dalam kategori aspek berpikir matematika tingkat tinggi yang terdiri atas empat aspek, yaitu penalaran matematika, komunikasi matematika, koneksi matematika, dan pemecahan masalah matematika [1]. Selain itu, kemampuan penalaran tercantum pada Peraturan Menteri No.23 Tahun 2006 tentang Standar Kompetensi Lulusan (SKL) yang menyebutkan bahwa mata pelajaran matematika bertujuan agar peserta didik memiliki kemampuan sebagai berikut.

a) Memahami konsep matematika, menjelaskan keterkaitan antarkonsep dan mengaplikasikan konsep atau logaritma, secara luwes, akurat, efisien, dan tepat, dalam pemecahan masalah.

b) Menggunakan penalaran pada pola dan sifat, melakukan manipulasi matematika dalam membuat generalisasi, menyusun bukti, atau menjelaskan gagasan dan pernyataan matematika.

c) Memecahkan masalah yang meliputi kemampuan memahami masalah, merancang model matematika, menyelesaiakan model dan menafsirkan solusi yang diperoleh.

d) Mengkomunikasikan gagasan dengan simbol, tabel, diagram, atau media lain untuk memperjelas keadaan atau masalah.

e) Memiliki sikap menghargai kegunaan matematika dalam kehidupan, yaitu memiliki rasa ingin tahu, perhatian, dan minat dalam mempelajari matematika, serta sikap ulet dan percaya diri dalam pemecahan masalah. [2]

Peserta didik mampu menarik sebuah kesimpulan dari berbagai fakta dan sumber yang relevan apabila pola berpikir peserta didik dikembangkan dalam proses pembelajaran matematika [3]. Oleh sebab itu sudah selayaknya penalaran mendapatkan perhatian khusus dalam pengembangan kualitas pembelajaran di sekolah.

Namun hingga saat ini, kemampuan penalaran matematis masih menjadi salah satu persoalan yang dihadapi peserta didik, khususnya dalam pembelajaran matematika. Hasil observasi yang dilakukan di salah satu Sekolah Menengah Pertama di Gorontalo, menunjukkan bahwa kemampuan penalaran matematis masih sangat rendah. Faktor yang menyebabkan rendahnya kemampuan penalaran matematis dapat bersumber dari peserta didik itu sendiri, guru, maupun kualitas pembelajaran. Hal ini senada dengan hasil penelitian pada [4] yang menyimpulkan bahwa motivasi mempunyai hubungan positif terhadap kemampuan penalaran matematis peserta didik. Dari segi kualitas pembelajaran, salah satu penyebab rendahnya kemampuan penalaran matematis bisa disebabkan karena pendekatan pembelajaran yang kurang tepat. Kemampuan guru dalam mengelola pembelajaran dapat berdampak pada keberhasilan peserta didik dalam proses belajar [5]. Permasalahan seperti ini menyebabkan aspek kemampuan berpikir dan aktivitas peserta didik tidak dapat berkembang. Beberapa penelitian terkait kemampuan penalaran matematis ataupun kemampuan berpikir kritis dapat dilihat pada [6][7]. 
Guru memiliki peran yang sangat penting dalam usaha peningkatan kemampuan penalaran peserta didik melalui pemilihan pendekatan yang tepat dalam proses pembelajaran. Guru perlu menyiapkan kegiatan pembelajaran yang dapat melibatkan kemampuan penalaran peserta didik dan menerapkannya dalam penyelesaian masalah di kehidupan sehari-hari [8]. Jila kemampuan yang akan dicapai penegasannya pada kemampuan penalaran untuk memecahkan suatu masalah yang berhubungan dengan kehidupan sehari-hari, maka hal yang memungkinkan pembelajaran matematika disajikan melalui masalah kontekstual, yaitu melalui pembelajaran kontekstual [9]. Pembelajaran kontekstual membantu siswa dalam mengeksplorasikan pemahaman dan kemampuan akademiknya secara aktif di dalam atau diluar kelas dengan berbagai variasi konteks. Pembelajaran dengan pendekatan kontekstual diharapkan sebagai solusi untuk menciptakan paradigma peserta didik belajar bukan paradigma guru mengajar seperti halnya terjadi pada pembelajaran langsung. Berdasarkan karakteristik dan kelebihan dari pembelajaran kontekstual, dapat diartikan bahwa pembelajaran kontekstual dapat mempengaruhi kemampuan penalaran matematis peserta didik dalam menyelesaikan permasalahan yang dihadapinya [10]. Beberapa penelitian telah dilakukan dengan menggunakan pembelajaran kontekstual dalam kaitannya dengan kemampuan representasi dan kemampuan pemecahan masalah terdapat pada [11][12].

Selain dari sisi guru dan pembelajaran, hal yang harus diperhatikan adalah dari sisi peserta didik yaitu karakteristik peserta didik. Karakteristik setiap individu berbedabeda, baik berbeda dalam kemampuan berpikir, kemampuan memecahkan masalah berbeda juga dalam memperoleh, menyimpan dan menerapkan pengetahuannya. Perbedaan-perbedaan yang menetap dalam diri seseorang baik dari segi menyusun, mengelolah informasi dan pengalaman-pengalaman ini dikenal dengan gaya kogntif [13]. Gaya kognitif dibedakan berdasarkan dimensi, yakni (a) perbedaan aspek psikologis, yaitu gaya kognitif Field Independence (FI) dan gaya kognitif Field Dependence (FD), (b) waktu pemahaman konsep, yaitu gaya impulsive dan gaya reflective [14].

Artikel ini membahas tentang gaya kognitif Field Independent (FI) dan Field Dependent (FD), dengan tujuan untuk mengetahui apakah terdapat pengaruh pendekatan kontekstual terhadap kemampuan penalaran matematis ditinjau dari gaya kognitif peserta didik.

\section{Metode}

Penelitian ini melibatkan sampel penelitian sebanyak 108 siswa Sekolah Menengah Pertama yang diperoleh dengan menggunakan teknik Multiple Stage Random Sampling. Jenis penelitian adalah Quasi Eksperimen dengan desain faktorial 2 × 2, analisis varian menggunakan varians dua jalur dan dilanjutkan dengan uji Tukey [15]. Pendekatan kontekstual sebagai variabel bebas, kemampuan penalaran matematis sebagai variabel terikat, dan gaya kognitif peserta didik sebagai variabel moderator yang digunakan untuk membedakan antara kelompok gaya kognitif Field Independent dan gaya kognitif Field Dependent. Dalam mengumpulkan data gaya kognitif peserta didik digunakan tes Group Embedded Figures Test (GEFT) dan untuk mengumpulkan data tentang kemampuan penalaran matematis peserta didik menggunakan instrumen tes yang dikembangkan oleh peneliti. 
Pengaruh Pendekatan Kontekstual terhadap Kemampuan Penalaran Matematis...

\section{Hasil dan Pembahasan}

Secara umum deskripsi data hasil kemampuan penalaran matematis disajikan pada Tabel 1.

Tabel 1. Deskripsi data hasil kemampuan penalaran matematis

\begin{tabular}{ccccccc}
\hline Data & $N$ & Skor Min & Skor Maks & Mean $(\bar{Y})$ & Modus $\left(M_{o}\right)$ & Median $\left(M_{e}\right)$ \\
\hline$A_{1}$ & 54 & 76 & 234 & 157,70 & 166,61 & 167,28 \\
$A_{2}$ & 54 & 87 & 198 & 148,72 & 158,08 & 151,83 \\
$B_{1}$ & 42 & 87 & 234 & 162,09 & 147,43 & 158,17 \\
$B_{2}$ & 66 & 76 & 198 & 150,22 & 178,76 & 152,64 \\
$A_{1} B_{1}$ & 22 & 140 & 234 & 182,68 & 188,06 & 182,93 \\
$A_{1} B_{2}$ & 32 & 76 & 183 & 145,81 & 135,50 & 147,50 \\
$A_{2} B_{1}$ & 20 & 87 & 186 & 140,50 & 132,50 & 141,50 \\
$A_{2} B_{2}$ & 34 & 97 & 198 & 155,50 & 172,35 & 158,83 \\
\hline
\end{tabular}

Keterangan:

$A_{1} \quad$ : Skor kemampuan penalaran matematis peserta didik yang dibelajarkan Pendekatan Kontekstual,

$A_{2}$ : Skor kemampuan penalaran matematis peserta didik yang dibelajarkan pembelajaran langsung,

$B_{1} \quad$ : Skor kemampuan penalaran matematis peserta didik yang terkategori mempunyai gaya kognitif field independent (FI),

$B_{2} \quad$ : Skor kemampuan penalaran matematis peserta didik yang terkategori mempunyai gaya kognitif field dependent (FD).

Berdasarkan informasi pada Tabel 1 diperoleh nilai rata-rata, nilai tengah, dan modus pada kelompok $A_{1} B_{1}$ paling tinggi dari semua kelompok yaitu 182,$68 ; 182,93$ dan 188,06. Temuan ini memberikan informasi bahwa peserta didik yang terkategori mempunyai gaya kognitif field independent (FI) yang dibelajarkan dengan pendekatan kontekstual mempunyai kemampuan penalaran matematis yang relatif tinggi dibadingkan dengan peserta didik dengan gaya kognitif field dependent (FD). Peserta didik yang terkategori mempunyai gaya kognitif field independent (FI) dengan dibelajarkan pendekatan kontekstual dalam menalar masalah matematika khususnya materi lingkaran dapat memahami dan menyelesaikan soal.

Selanjutnya pengujian hipotesis menggunakan analisis variansi dua jalur (ANAVA $2 \mathrm{x}$ 2) dan uji Tukey. Analisis varians dua jalur adalah suatu teknik penghitungan (statistik parametrik) yang bertujuan untuk menyelidiki dua pengaruh, yaitu pengaruh utama dan pengaruh interaksi. Pengaruh "utama" di sini adalah pengaruh perbedaan Pendekatan Kontekstual dan Pembelajaran Langsung terhadap kemampuan penalaran matematis, dan juga pengaruh perbedaan gaya kognitif terhadap kemampuan penalaran matematis. Pengaruh "interaksi" yang dimaksud adalah pengaruh interaksi antara pembelajaran dan gaya kognitif peserta didik terhadap kemampuan penalaran matematis. Hasil perhitungan varians 2 jalur ini secara ringkas dapat dilihat pada Tabel 2. 
Tabel 2. Rangkuman Hasil Perhitungan ANAVA Data Kemampuan Penalaran Matematis

\begin{tabular}{lcccccc}
\hline Sumber Varians & $\begin{array}{c}\text { Jumlah } \\
\text { Kuadrat } \\
(J K)\end{array}$ & $\begin{array}{c}\text { Derajat } \\
\text { Kebebasa } \\
\mathrm{n}(d k)\end{array}$ & $\begin{array}{c}\text { Rata-rata } \\
\text { Jumlah } \\
\text { Kuadrat } \\
(R K)\end{array}$ & $F_{\text {hitung }}$ & $\begin{array}{c}F_{\text {tabel }} \\
=0,05\end{array}$ & $\begin{array}{c}\text { Keputusa } \\
\mathrm{n}\end{array}$ \\
\hline $\begin{array}{l}\text { Pembelajaran } \\
(A)\end{array}$ & 3322,23 & 1 & 3322,23 & 5,1606 & 3,94 & $H_{0}$ ditolak \\
$\begin{array}{l}\text { Gaya kognitif } \\
(B)\end{array}$ & 5988,61 & 1 & 5988,61 & 9,3026 & 3,94 & $H_{0}$ ditolak \\
$\begin{array}{l}\text { Interaksi } \\
\begin{array}{l}\text { Pembelajaran } \\
\text { dan Gaya }\end{array}\end{array}$ & 17387,76 & 1 & 17387,76 & 27,0098 & 3,94 & $H_{0}$ ditolak \\
kognitif $(A B)$ & & & & & & \\
$\begin{array}{l}\text { Kekeliruan } \\
\text { dalam sel }(d)\end{array}$ & 66950,84 & 104 & 643,76 & - & - & \\
\hline Total $(T)$ & 93649,44 & 107 & 27342,36 & & & \\
\hline
\end{tabular}

Hasil perhitungan dengan menggunakan uji $F$ diperoleh $F_{\text {hitung }}$ yang ternyata lebih besar dari nilai $F_{\text {tabel }}$ pada taraf signifikan $5 \%$. Hal ini berarti pada pembelajaran kontekstual, kemampuan penalaran peserta didik lebih baik dari pada dibelajarkan dengan pembelajaran langsung. Kemampuan penalaran matematis peserta didik yang terkategori mempunyai gaya kognitif Field Independent lebih baik daripada peserta didik yang terkategori mempunyai gaya kognitif Field Dependent, dan terdapat pengaruh interaksi antara pendekatan pembelajaran dan gaya kognitif terhadap kemampuan penalaran matematis. Pengaruh interaksi ditunjukkan pada Gambar 1.

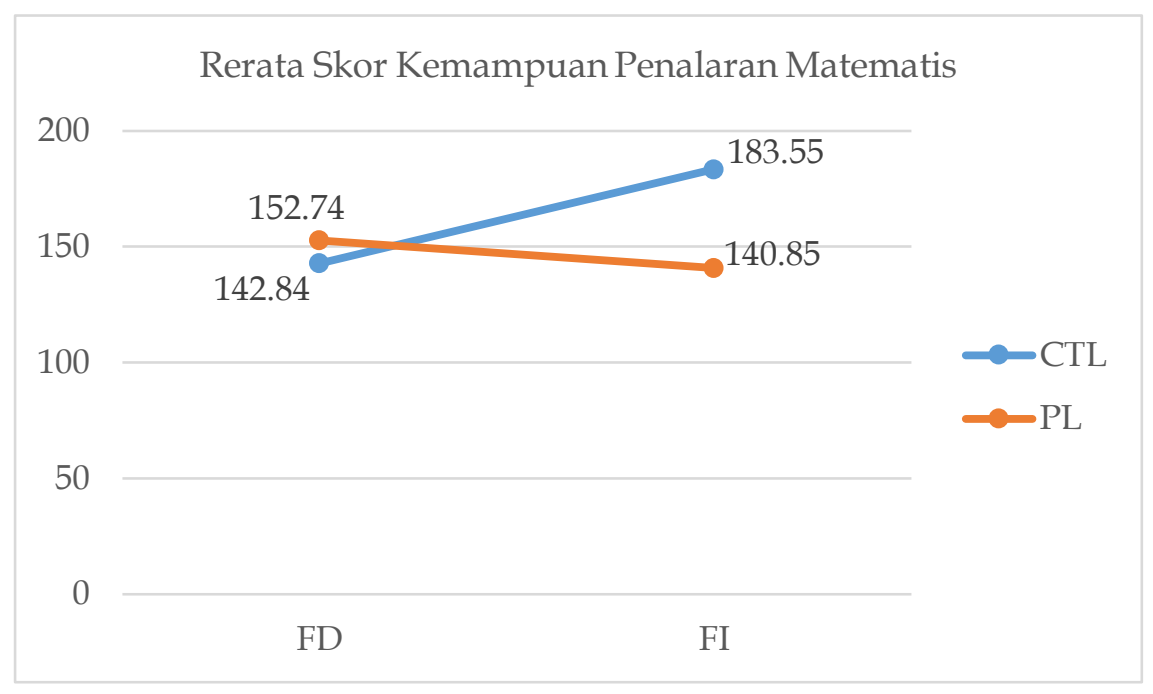

Gambar 1. Kurva interaksi data antara pendekatan pembelajaran dan gaya kognitif peserta didik terhadap kemampuan penalaran matematis 
Adanya interaksi di antara variabel-variabel penelitian maka selanjutnya dapat dilakukan perhitungan uji lanjut menggunakan uji Tukey. Hasil perhitungan uji Tukey disajikan pada Tabel 3.

Tabel 3. Hasil perhitungan uji Tukey

\begin{tabular}{cccccc} 
No. & Kelompok & $\mathrm{t}_{\text {hitung }}$ & $\mathrm{t}_{\text {tabel }(0.01)}$ & $\mathrm{t}_{\text {tabel }(0.05)}$ & Keputusan \\
\hline 1 & A1B1 dengan A1B2 & 5,792 & 2,358 & 1,658 & $H_{0}$ ditolak \\
2 & A2B1 dengan A2B2 & 1,935 & 2,358 & 1,658 & $H_{0}$ ditolak \\
3 & A1B1 dengan A2B1 & 5,447 & 2,358 & 1,658 & $H_{0}$ ditolak \\
4 & A1B2 dengan A2B2 & 1,583 & 2,358 & 1,658 & $H_{0}$ diterima \\
\hline
\end{tabular}

Pengujian hipotesis menunjukkan bahwa nilai rata-rata kemampuan penalaran matematis peserta didik yang pembelajarannya menggunakan pendekatan kontekstual dan nilai rata-rata kemampuan penalaran matematis peserta didik yang pembelajarannya menggunakan pembelajaran langsung, jika masing-masing kelompok mempunyai gaya kognitif FI akan berbeda secara signifikan. Berdasarkan hasil perhitungan uji lanjut menggunakan uji $t$, diperoleh $t_{\text {hitung }}=5,446>t_{\text {tabel }(0,05)}=$ 1,658 sehingga $H_{0}$ ditolak, artinya terdapat perbedaan secara signifikan antara peserta didik yang menggunakan pendekatan kontekstual gaya kognitif FI $\left(\mathrm{A}_{1} \mathrm{~B}_{1}\right)$ dan peserta didik yang menggunakan pembelajaran langsung gaya kognitif FI $\left(\mathrm{A}_{2} \mathrm{~B}_{1}\right)$. Dengan demikian dapat disimpulkan bahwa jika masing-masing kelompok mempunyai gaya kognitif FI maka nilai rata-rata kemampuan penalaran matematis peserta didik yang pembelajarannya menggunakan pendekatan kontekstual lebih tinggi dari nilai rata-rata kemampuan penalaran matematika peserta didik yang pembelajarannya menggunakan pembelajaran langsung.

Temuan penelitian ini membuktikan bahwa peserta didik yang terkategori mempunyai gaya kognitif FI lebih efektif diberikan pembelajaran pendekatan kontekstual daripada diberikan pembelajaran langsung. Hal ini disebabkan peserta didik yang terkategori mempunyai gaya kognitif FI mempunyai ciri: cara berpikir analitis, mempunyai motivasi internal cukup kuat, dan bersifat individual tanpa memerlukan bantuan orang lain. Hal ini sesuai dengan salah satu komponen dari pendekatan kontekstual yaitu mengembangkan pemikiran bahwa peserta didik akan belajar lebih bermakna dengan cara bekerja sendiri, menentukan sendiri dan mengkonstruksi sendiri dalam mencari pengetahuan dan keterampilan barunya.

Adapun pembelajaran langsung mempunyai ciri segala sesuatu yang dipelajari tidak dihubungkan dengan kebutuhan dan kebermaknaan pembelajaran. Tidak menantang artinya bahwa pembelajaran langsung bersifat tidak untuk memecahkan masalah nyata. Peserta didik diajak untuk mendiskusikan pemasalahan dalam pengetahuan dan konsep baru. Pasif artinya bahwa pembelajaran langsung tidak memberikan kesempatan agar pembelajaran dapat berpikir kritis dalam menyusun makna terhadap sesuatu yang dipelajarinya. Artinya peserta didik dalam pelajaran ini tidak diajak untuk berpikir kritis sehingga peserta didik tidak dapat mengembangkan berpikir analitis dan motivasi internalnya tidak muncul. 


\section{N.A. Yunus, et.al}

Contoh jawaban peserta didik yang terkategori mempunyai gaya kognitif FI dalam mengerjakan tes di kelas yang menggunakan pendekatan kontekstual dengan soal:

"Perhatikan gambar di bawah!

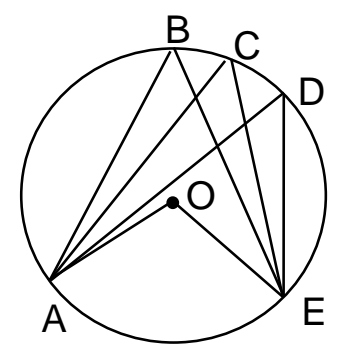

Titik O merupakan titik pusat lingkaran. Jika besar $\angle A B E+$ besar $\angle A C E+$ besar $\angle A D E=$ $81^{\circ}$. Tentukan besar $\angle A O E^{\prime \prime}$

Contoh jawaban peserta didik 1 ditampilkan pada Gambar 2.

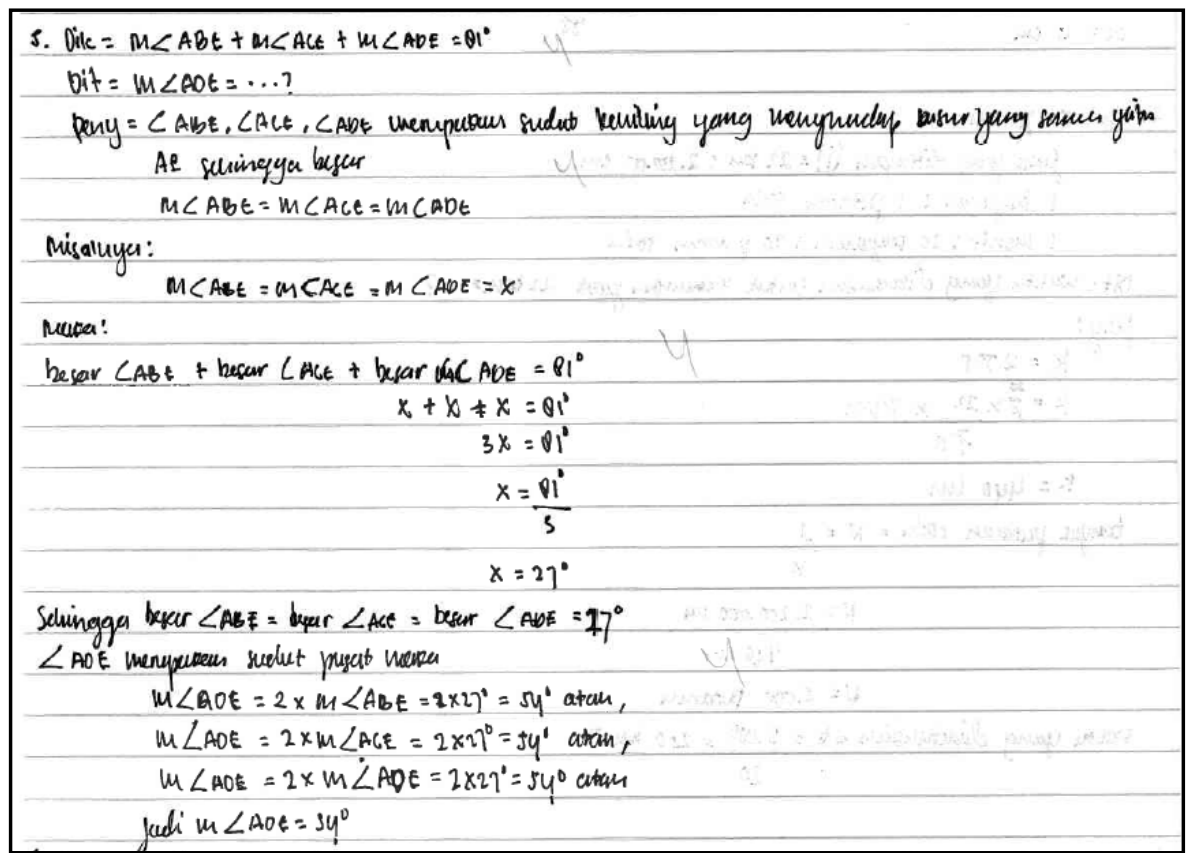

Gambar 2 Jawaban peserta didik yang terkategori mempunyai gaya kognitif FI pada pembelajaran pendekatan kontekstual

Dari jawaban peserta didik tampak bahwa untuk semua indikator kemampuan penalaran mendapat skor maksimal karena peserta didik telah melakukan manipulasi matematika, mampu mengajukan dugaan dan ide dalam bentuk kalimat matematika, mampu menyusun bukti, memberikan bukti terhadap kebenaran solusi dan mampu menarik kesimpulan dengan benar.

Salah satu jawaban dari peserta didik gaya kognitif FI yang mengikuti pembelajaran langsung ditampilkan pada Gambar 3. 


$\begin{aligned} \text { Sudut pusat } & =2 \times \text { sudut keliling } \\ & =2 \times 27 \\ & =54^{\circ} \\ \text { Jadi, Besar } & \leq 40 E \text { atau sudut pusat adalah } 54^{\circ}\end{aligned}$

Gambar 3 Jawaban peserta didik yang terkategori mempunyai gaya kognitif FI pada pembelajaran langsung

Dari jawaban peserta didik tampak bahwa peserta didik telah mampu mengajukan dugaan dan ide dalam bentuk kalimat matematika dan mampu menarik kesimpulan namun belum mampu memberikan bukti terhadap kebenaran solusi dan melakukan manipulasi matematika.

Dengan demikian dapat dinyatakan bahwa pendekatan kontekstual lebih cocok dibelajarkan pada peserta didik yang terkategori mempunyai gaya kognitif Field Independent (FI).

\section{Kesimpulan}

Kemampuan penalaran peserta didik yang diajar dengan pendekatan kontekstual lebih baik daripada peserta didik yang diajar dengan pembelajaran langsung. Selanjutnya dari segi gaya kognitif, peserta didik gaya kognitif Field Independent (FI) yang dibelajarkan dengan pendekatan kontekstual mempunyai kemampuan penalaran matematis yang relatif tinggi dibadingkan dengan peserta didik gaya kognitif Field Dependent (FD). Hal ini menunjukkan bahwa Pendekatan Kontekstual baik digunakan pada peserta didik yang mempunyai gaya kognitif Field Independent (FI) untuk meningkatkan kemampuan penalaran matematis.

\section{Referensi}

[1] NCTM, "Principle and Standards for School Mathematics." [Online]. Available: http://www.nctm.org. [Accessed: 20-Sep-2018].

[2] DEPDIKNAS, "Standar Kompetensi Matematika SMP." [Online]. Available: http://www.puskur.net. [Accessed: 19-Sep-2018].

[3] A. Banasuru, Filsafat dan Filsafat Ilmu. Bandung: Alfabeta, 2013.

[4] B. I. Sappaile, "Hubungan Kemampuan Penalaran dalam Matematika dan Motivasi Berprestasi terhadap Prestasi Belajar Matematika," J. Pendidik. dan Kebud., vol. 13, no. 69, pp. 985-1003, 2007.

[5] R. Resmawan, "Hubungan antara Pesepsi Mahasiswa terhadap Keterampilan Dosen dalam Mengelola Kelas dengan Hasil Belajar Mahasiswa Jurusan Pendidikan Matematika," J. Euler, vol. 2, no. 2, pp. 129-134, 2014.

[6] M. D. Kurniasih, "Pengaruh Pembelajaran React terhadap Kemampuan Berpikir Kritis Matematis Ditinjau dari Habit of Mind Mahasiswa," J. Pendidik. Mat., vol. 2, no. 1, pp. 29-38, 2017. 


\section{N.A. Yunus, et.al}

[7] W. Hidayat, "Adversity Quotient dan Penalaran Kreatif Matematis Siswa SMA dalam Pembelajaran Argument Driven Inquiry pada Materi Turunan Fungsi," J. Pendidik. Mat., vol. 2, no. 1, pp. 15-28, 2017.

[8] A. Amir, "Kemampuan Penalaran dan Komunikasi dalam Pembelajaran Matematika," Logaritma J. Ilmu-Ilmu Pendidik. dan Sains, vol. 2, no. 1, pp. 18-33, 2014.

[9] S. Bahri, "Peningkatan Kemampuan Pemecahan Masalah dan Koneksi Matematika Siswa dengan Pendekatan Kontekstual (Contekstual Teaching and Learning) di SMA Swasta Al-Azhar Medan," Universitas Muslim Nusantara Al-Washliyah, 2011.

[10] M. Muslich, KTSP Pembelajaran Berbasis Kompetensi dan Kontekstual. Jakarta: Bumi Aksara, 2009.

[11] K. Hutagaol, "Pembelajaran Kontekstual untuk Meningkatkan Kemampuan Representasi Matematis Siswa Sekolah Menengah Pertama," Infin. J., vol. 2, no. 1, pp. 85-99, 2013.

[12] M. F. Amir, "Pengaruh Pembelajaran Kontekstual terhadap Kemampuan Pemecahan Masalah Matematika Siswa Sekolah Dasar," in Seminar Nasional Pendidikan, 2015, pp. 34-42.

[13] Slameto, Belajar dan Faktor yang Mempengaruhi. Jakarta: Rineka Cipta, 2003.

[14] S. Arikunto, Prosedur Penelitian. Jakarta: Rineka Cipta, 2010.

[15] N. Abbas, “Bahan Ajar Statistik Penelitian,” Gorontalo, 2012. 